\title{
For a comparative sociology of home: Relationships, cultures, structures
}

\author{
Paolo Boccagni \\ University of Trento, Italy

\section{Margarethe Kusenbach} \\ University of South Florida, USA
}

\begin{abstract}
Home matters, for people's everyday life and for social research, in ways that are still lacking a systematic sociological framework of analysis. As a contribution toward this framework, we define home as an emplaced relationship that prioritizes certain socio-material contexts over others, by virtue of the emotional, affective and practical values attached to them, in forms and degrees that change over space and time. This understanding highlights the interdependence between relational, cultural and structural aspects of home as a distinctive social experience. We then connect the sociological debate with the discourse on home across social sciences more broadly, with a particular emphasis on the heuristics, practices and multiscalarity of home. In terms of practical research, the methodological bases of 'home studies' are still in development, also regarding the prospects of translating and comparing home across socio-cultural and spatial contexts. Nonetheless, this Special Issue of Current Sociology opens up new ways to advance the field of home studies - theoretically in our opening paper, and empirically in the six articles that follow.
\end{abstract}

\section{Keywords}

Comparative research, culture, home, methods, relationships, social structures, sociology

\section{Corresponding author:}

Paolo Boccagni, Department of Sociology and Social Research, University of Trento, via Verdi 26, Trento, $38 \mid 22$, Italy.

Email: paolo.boccagni@unitn.it 


\section{Introduction}

Over the past two decades, home, a seemingly obvious notion that resonates deeply in people's life experience and imagination, has been increasingly scrutizined as a topic in the social sciences and humanities. Its potential as a heuristic notion, a research setting and a subject in itself can easily be appreciated in cross-disciplinary fields such as housing and urban studies, migration, refugee and mobility studies and ageing and life course research, to give but a few examples. Against this backdrop, this Special Issue of Current Sociology aims to produce an original, empirically-based and comparative understanding of the spatial and cultural bases of home across contemporary societies. Our own contribution as editors, in particular, argues that a sociological understanding of home cannot simply refer to a location, a material artefact, and/or a background feature of everyday life. Rather, we argue that such an understanding must be inherently relational. More precisely, the concept of home - which, importantly, also signifies the absence as well as the tyranny of home - can be used to capture the complex social relationships that exist between individuals or groups and certain built environments, social settings and material cultures to which people attach unique meanings and functions. In short, home is a privileged site for studying processes of place-making, mobility, identity, emotion and belonging, as well as majority-minority relations, at both local and global scales.

In all of these respects, an increasing interest in home can be detected across social sciences as a corollary of other substantive topics, yet also as a topic of research in its own right. In our particular cases, the interest in studying home stems from previous concerns with migration, emplacement and circulation (for Boccagni), as well as housing, communities and emotions (for Kusenbach). Grounded in these diverse impulses, in what follows we advance a sociological understanding of home, and a related methodological agenda, with a view toward highlighting three fundamental points: first, the inherently relational origin of all that is called, felt or claimed as home, involving interpersonal relationships with humans and domestic animals, yet also, to some extent, connections with 'inanimate' built, material or natural settings; second, a need to take into account the constellations of societal norms and values that shape distinct cultural ways of cultivating, displaying and emplacing home; and third, attention to the intersection between views, emotions and experiences of home and underlying social structural forces. Power differentials and structural inequalities result in an unequal distribution of resources, access and rights for individuals or groups to make themselves at home under particular spatio-temporal circumstances.

\section{Toward a sociological understanding of home}

Theoretical reflections and empirical studies about home can be found across all social sciences and humanities - making up what, by now, can be called the interdisciplinary field of home studies. However, reflection and research on home in sociology is less extensive than in other disciplines, such as geography and anthropology. While the importance of 'a space for place in sociology' has been generally recognized (Gieryn, 2000), the same has not yet occurred for the particular place of home (even though there are exceptions, including Anderson et al., 2016; Duyvendak, 2011; Kusenbach and 
Paulsen, 2013). For sure, a topic that links everyday life to virtually all other social science and humanities fields must not overemphasize disciplinary boundaries. Nonetheless, there is a promise in elaborating the particular insights that sociology can provide to research on home, once the concept is appreciated in sufficient depth and complexity rather than being conflated with house, household or community. In our view, the promise of a sociology of home lies in the three analytical levels - relationships, cultures and structures - that make up the building blocks of a uniquely sociological definition of home.

\section{Defining home}

As a category of practice, home is typically a common sense, unreflexive notion - something that apparently is already given out there. There is no need to wonder about its meaning in people's everyday lives, unless under special circumstances, in which home is absent, missing or patently at odds with the normatively positive attributes it 'should' hold. In fact, when being at home, people link personal, emotional experiences of familiarity, haven and heaven in particular material environments (Duyvendak, 2011) with cultural and socio-structural ideas of what is desirable and appropriate for someone like them (Paulsen, 2013). Home is both an emotion and a place imbued with meaning generated through the everyday life routines enacted in it, the sense of protection and intimacy it emanates, and the largely positive memories of the past (and possibly future aspirations) it may elicit.

In short, what we tend to call home is unquestionably 'our' place, where our presence needs no justification - a place of normality. However, none of home's normatively positive attributes, whether we achieve them or not, is ever self-evident or self-produced. The qualities people associate with home are obviously related to certain infrastructural aspects, but they are also the fruit of their own sustained, if mostly unnoticed, relational work, and of their resources and opportunities (or lack thereof) to enact it. What we think or feel of as home depends on the meaningful relationships we have developed with other people, e.g. partners, family members or fictive kin, who share the same space (cf. Smart, 2007). Generally speaking, home has to do with a significant relational engagement, or with people's need and desire to attach a sense of security, familiarity and control to some portion of their life circumstances (Boccagni, 2017). Home, then, is a process rather than a state of things; and ultimately, more existentially, a matter of hom-ing, or a life-long effort to reach this 'ideal' social condition that generates affect, longing and aspiration, while being very difficult to materialize in full.

Even in the here-and-now, a sense of home, wherever and whenever located, is a matter of degrees and thresholds (Boccagni and Brighenti, 2017), rather than a full and unconditional achievement. Home stems from the interactions between individual or group views, emotions and practices, the assets they rely upon, and the external structures of opportunity that enable and constrain their social actions. Against the fallacy of an unneccessarily romanticized and abstract notion of home, but also against the view of home as synonymous with house or dwelling, a sociological understanding stresses the in-betweenness of home as a bundle of ongoing social relationships - a situated experience of some familiar environment as different from, and in a way premier to, all others. 


\section{From home as relationships to cultures and structures of home}

For sure, the endeavour of making (oneself at) home is not the same, nor is it equally 'successful', for everyone. Both constructions of what home is like and perceptions of being more or less at home (or, more pragmatically, at home enough) vary enormously through time and space. This variability also applies to the other two dimensions of our sociological approach to home, i.e. cultures and structures. To fully understand home as a concept, one must take into account the larger relational, cultural and socio-structural contexts and horizons within which it is embedded.

If home rests on the cultivation and emplacement of particular social relationships, it can hardly have an autonomous existence without them. Rather, it needs to be understood in light of the 'social life' of relationships themselves. This brings into the debate, first, the cultural aspects of home - meaning what is culturally regarded as a 'good' or 'appropriate' home, regarding its material infrastructure, but also the ways of decorating and using a dwelling, or any equivalent homely space (Rybczynski, 1987). Across time and societies, there are significant variations in the cultural views and values that shape the meanings and functions of domestic space, including internal boundaries and thresholds between different parts of a dwelling and different ways of appropriating them. There are also major variations in the ways in which gender, intimate and generational relationships shape the access and use of domestic space (e.g. Easthope et al., 2015; Mallett, 2004); or, different again, in the ways in which external divides such as public versus private, or secular versus sacred, are reproduced on a smaller scale within the place one would call home (Martsin and Niit, 2005).

In all of these respects, homemaking is less an individual matter than a household affair and, indeed, a societal concern (Atkinson and Jacobs, 2016). It is fundamentally and differentially shaped by people's individual capacities, household and network resources, cultural backgrounds and socio-demographics. This involves not only the economic assets available (as exemplified in homeownership), but also the influence of variables such as age, gender, sexuality and stage in the life course, among others. The strength and the qualities of people's senses of home are not necessarily the same for children, youth, adults, or the elderly; for women versus men; for those with mainstream versus non-normative sexualities. For instance, depending on one's position in the life course, home may have more to do with the material environment as such, or with the strength of the affective ties inside it. In either case, a 'positive' sense of home tends to be related to time, that is, to the length of one's voluntary residence in a particular place (Vanzella-Young, 2019; Werner et al., 1985).

Home as a social practice, then, is a privileged entry point into individual biographies, just like the home, as a built, material environment, can be ethnographically appreciated as a microcosm of society (Bourdieu, 1977 [1970]; Carsten and Hugh-Jones, 1995) - a focal point for the study of broader societal arrangements, values and patterns of social structure and inequality, starting with the everyday bases of life experience and social reproduction.

\section{Home as a category in the social sciences: Heuristics, practices, scales}

There is, however, no need in sociology, or in other disciplines, to define home in a overly narrow way. Admittedly, the variability of home and its meanings in people's lives 
raise challenges for its use as a unit and a category of analysis. Yet, the multivalence of home is also what makes the concept rich, thick and heuristically powerful in connecting distinct realms of materiality, emotion, place and value (Tolia-Kelly, 2016). The multidimensionality of home and of the social experiences associated with it, then, is part and parcel of its analytical power.

With this premise in mind, we can distinguish at least three ways of using home across social sciences (and, parallel to that, in everyday life): as a heuristic notion, a distinctive set of practices, and a multiscalar socio-material setting. Home thus matters for social research primarily as a research heuristic (i.e. a practical idea, or a word in use, with the attendant cognitive and emotional categorizations), as a research subject (i.e. a complex assemblage of social relationships and practices), and as a research venue (i.e. a sociomaterial setting on a variety of scales, potentially ranging from the individual body, to a building, to larger portions of the built and/or natural environment).

\section{On the heuristic power of home}

To begin with, the concept of home provides a brilliant shortcut to highlight micromacro intersections between identities, emotions, cultures and social structures. Home is a 'keyhole' concept which allows scholars to bundle together, as well as disentangle, central strands of research in the social sciences in innovative ways. In this sense, home functions like a 'keystone' species in biology (Mills et al., 1993) - an organism that is crucially needed to keep an ecosystem intact and in balance. In a similar vein, home lies at the core of people's everyday life experience. As such, the concept is easy to understand and rings 'true' for everyone's life circumstances, including for those living in situations that are deeply unhomely (e.g. Van der Horst, 2004, on asylum seekers; McCarthy, 2018, on the homeless; Price, 2002, about the experience of domestic violence). As a matter of fact, due to its taken-for-granted quality, the social and biographical significance of home is fully illuminated only by its absence or loss, or by a diminished sense of it, as several contributions in this Special Issue reveal.

Moreover, home has a remarkable power as a metaphor or discursive category (Boccagni et al., 2020). As a word, it evokes an elemental differentiation of the social world into two parts: an inside, constructed as personal and intimate, and an outside that may hold opposite qualities. Home can then be mobilized in all sorts of public contexts; more often than not, in ways that enhance the distinction between insider (or long-term resident) and outsider groups (or newcomers), with the former typically constructed as more deserving than the latter (Walters, 2004). Along these lines, home as a metaphor no less than a 'real' place - assumes a remarkable political significance, similar to the experiences and politics of belonging (Kusenbach, 2019).

\section{Home as practice}

Second, home is increasingly understood as a set of practices that make a place homelike, in agreement with the broader literature on place-making and the social construction of place. In this perspective, home is viewed as a particular form of doing that is 'performed' by individuals in interactions with specific and imagined audiences, as captured 
by Erving Goffman's 'dramaturgical' perspective in sociology and by theories of 'performativity' in the humanities.

Clearly, the expected skills and steps involved in 'doing' home vary by gender, age, life stage, class, and many other structural variables. They are culturally constructed and legitimized, and they are taught and learned through various processes of socialization, for instance in the household, in neighbourhood and schools, among peers, yet also through consumption and popular media. Entire industry branches cater to cultural performances of what it means to learn and do homemaking properly. Domestic homemaking and care work across many cultures are typically viewed as domains of women. This highlights the importance of a gender-sensitive lens (e.g. Bowlby et al., 1997; Longhurst, 2012; Young, 2002) when examining home, alongside intersectional issues of age, race/ ethnicity, class, sexuality, health/ability and migration.

Understanding home as a specific social practice, rather than a location, has the distinct advantage of moving research on homemaking away from proper home-like settings into other spaces, thereby offering opportunities for a better understanding of transient, multiple and incomplete homes, as well as homemaking in non-domestic and even public spaces - anywhere where people put forth ownership claims, however minimal and temporary, over slivers of space (Boccagni and Duyvendak, 2019).

\section{On location(s) and scale(s) of home}

As a third point, while we approach home as a spatialized research setting, we need to cope with its elusive multiscalarity. Both in social research and in everyday life, home may refer to a dwelling or a house as much as to extra-domestic territories of origin, identification or belonging (Kusenbach and Paulsen, 2019). Just like belonging, home can be used to capture people's connections to places ranging from transnational regions to neighbourhoods to rooms. Indeed, most people develop nested feelings of home regarding differently scaled locations, eliciting more or less 'thick' senses of home depending on particular social and temporal circumstances.

For instance, research has shown that migrants and refugees may feel at home in their neighbourhoods and other local communities, while they might be uncomfortable in their apartments and rooms, and possibly also feel estranged from the nations and larger cultures in which they reside (e.g. Hondagneu-Sotelo, 2017). Particularly during early stages of the displacement and mobility process, immigrants tend to frame their (typically far away) communities of origin as the only and exclusive home (Boccagni, 2017). Over time, and under particularly harsh conditions, they may learn to feel at home in virtual space and mediated interactions, far more than in the material infrastructures or the larger communities in which they actually reside (Horst and Miller, 2013).

On all these scales, the (re)production of a sense of home cannot be reduced to ascriptive or infrastructural variables. It also fundamentally hinges on the ways of doing things, and on the related emotional and sensuous experiences, leading to a tentative appropriation and personalization - in short, domestication - of some portion of space. This claim for domestication can be a source of contention and conflict within and between social groups, regardless of the scale of reference. In all these varying material or virtual environments, the home lens illuminates different sets of social relationships (family, fictive 
kin, friends, colleagues, co-nationals, etc.) that are surrounded by culturally normative ideas and deeply embedded in structural power hierarchies.

\section{Researching home: Taking stock and ways forward}

As a social experience, therefore, home can be investigated at micro, meso and macro levels, and at their mutual intersections, as a topic in itself or as a part of larger scholarly conversations. Moreover, research on home can be particularly productive and revealing when it involves 'social margins' - that is, wherever an ordinary or taken-for-granted sense of home is missing or weakened. This may be the case for many social groups, ranging from the homeless to travellers, from migrants to refugees. However it may also apply to women, teenagers, seniors, disabled people, or any marginalized group of people who attach no or little sense of home to the place(s) where they actually live (or sleep, eat, work, play). The papers by Vandenbeld Giles, Kim and Smets, Steigemann and Misselwitz, and Basso and colleagues in this Special Issue are cases in point. Whatever the group or category, the promises and dilemmas of experiencing home are likely to change over time, parallel to the individual and collective life course. In this light, examining the remembered and imagined aspects of home within various social groups at moments of social transitions can be especially interesting and important.

Even under the best of circumstances, conducting original research on the lived experience of home is not without challenges. Scholarly discussion in this regard is often speculative, prescriptive, even ideological. Rather than normatively portraying home as something inherently desirable or good, the challenge for theoretically informed social research is to investigate, first, what home actually means to whom, under what circumstances, and why; and second, how far, if at all, the 'actual' home experience matches the 'aspired' one, given the unequal social distribution of opportunities, access and rights of people to make themselves at home, and the factors that account for this inequality. Much of the current research privileges people's narratives, hence their memories or aspirations of home, together with the underlying cognitions, moralities and value constellations. There is a particular merit, however, in excavating the social and political material practices whereby individuals and groups (un)make home; put otherwise, in investigating how home is co-produced, negotiated, mobilized and challenged practically, rather than only 'told'; how it is embedded in broader housing, living and working conditions and trajectories; how it is variably shaped by social structural and ecological factors. Again, the very ability to feel at home and to make oneself at home is an unevenly distributed resource, reflective of deeper patterns of inequality.

While getting access to the privacy of domestic environments raises practical, legal and ethical constraints for researchers, pioneering scholarly efforts have been made to reconstruct home experiences from within, via home tours, visual ethnographies, participatory or mobile methods, and so forth (Boccagni et al., 2020). Likewise, the interfaces between domestic and semi-public or public facets of home experiences, and between material and immaterial aspects, have been investigated in several national and local contexts, as well as comparatively between them on occasion (Kusenbach and Paulsen, 2013; Miranda et al., 2020). 
Within the rich terrain of home research, the articles in this Special Issue build on a range of methodological strategies, including team research (Kim and Smets, Steigemann and Misselwitz), creative document research (Cheshire and ten Have), historical comparative research (Basso et al.), ethnographic fieldwork and interviews with vulnerable people in neglected locations (Vandenbeld Giles), and observations of material cultures, combined with biographical recollections of those who use them (Pechurina).

To conclude, the future potential of social research on home should be viewed in light of two critical developments, the first having to do with translation and the second with comparison. To begin with, there is little obvious in translating the sets of meanings, emotions and moralities associated with home across languages, but also across the divides created by national, ethnic or cultural belongings, as well as by 'ordinary' demographics (class, education, gender, sexuality, age, health, race, life course stage). People's positions along these divides shape, to some extent, what home means or should mean in their lives. How home circulates across different languages, spatial, ethno-national or demographic backgrounds is an emerging research topic in itself, as attested by scholarship on mobility, migration and cultural diffusion (Boccagni et al., 2020).

At the same time, a case can be made for some fundamental commmonality regarding the aspirational dimensions of home - security, familiarity, control, intimacy, comfort, personal expression - regardless of social and cultural divides. Moreover, looking at what people actually do to make themselves at home, in light of their assets and opportunity structures, is no less important than attending to what they mean by home. Accordingly, another important form of translation - or rather, of open interdependence - is the one between people's views and emotions of home (which are, of course, socially constructed) and the social practices through which these become articulated and materialized (what could be referred to as the social production of home).

Still another important question involves comparative research, that is, the multisited study of social experiences of home across spatial and temporal coordinates, between different groups, and indeed, between different case studies of home. As, again, research on migrant homemaking has revealed (Miranda et al., 2020), inter-group comparison should not only transcend the most obvious or politically salient divides, such as natives versus immigrants, or long-term residents versus newcomers. A variety of other variables and sets of practices are equally significant for inter-group comparison. As important, in light of the multifaceted meanings and functions of home, will be to unpack the notion of home itself, whether as an infrastructure, a relational attachment, an emotion, etc., for different comparative purposes. At a general level, few things are arguably as universal as people's need to feel at home, to make themselves at home, and to have at least some shelter to which a rudimentary sense of home can be attached over time. Nonetheless, accounting for comparative experiences of home along these lines, and the variety of the word's uses for various social purposes, lies at the heart of a subfield of research that is still underdeveloped.

All in all, this Special Issue of Current Sociology illustrates the potential for taking significant steps in these directions. It does so by facilitating dialogue among, and comparison across, a variety of housing and home contexts, research participants, and global regions. The following contributions include research conducted in Canada, Australia, the Netherlands, Germany and Great Britain. However, the geographic origin of research 
participants represented in these works extends beyond Western nations to include Syria, Iran, Iraq, Afghanistan, Eritrea and Russia, as well as including the Sayisi Dene, a First Nation people of Canada. The volume as a whole advances the debate on the contemporary experience and politics of home, based on research into different scales, units of analysis and housing configurations, from migrant residents of asylum facilities (Kim and Smets; Steigemann and Misselwitz) to homeless families in precarious accommodation (Vandenbeld Giles) and feuding households in suburban middle class neighbourhoods (Cheshire and ten Have); from life experiences of single individuals with migrant backgrounds (Pechurina) to the tragic history of an aboriginal people (Basso et al.). In short, the six articles in this Special Issue represent a diversity of theoretical frameworks, methodological approaches, geographic regions, levels of analysis, and aspects of homemaking in daily life, offering a microcosm of current research in the quickly growing area of the sociology of home, and of home studies more generally. Together, these articles exemplify a deeply relational approach to home as both a social experience and social structure which, in our view, encompasses sociology's unique and important contribution to home studies.

\section{Acknowledgements}

The articles in this Special Issue were initially discussed in two sessions organized by RC43 Housing and the Built Environment, at the ISA World Congress of Sociology, Toronto, July 2018. These sessions, on Researching home: Choices, challenges, opportunities, were co-convened by Paolo Boccagni and Margarethe Kusenbach. Moreover, some of the ideas presented in this article were developed within the framework of the research project HOMInG - The home-migration nexus (ERC StG 678456, 2016-2021), based at the University of Trento and led by Paolo Boccagni.

\section{Funding}

The research in this article was supported by the European Research Council (HOMInG, ERC StG 678456).

\section{ORCID iD}

Paolo Boccagni (iD https://orcid.org/0000-0001-8379-8561

\section{References}

Anderson G, Moore J and Susky L (eds) (2016) Sociology of Home. Toronto: Canadian Scholars' Press.

Atkinson R and Jacobs K (2016) Home, House and Society. Basingstoke: Palgrave.

Boccagni P (2017) Migration and the Search for Home. New York: Palgrave.

Boccagni P and Brighenti AM (2017) Immigrants and home in the making. Journal of Housing and the Built Environment 32(1): 1-11.

Boccagni P and Duyvendak JW (2019) On the 'scaling up' of home in majority-minority relations. HOMInG WP 6/2019.

Boccagni P, Pérez Murcia L and Belloni M (2020) Thinking Home on the Move. London: Emerald, forthcoming.

Bourdieu P (1977 [1970]) The Kabyle house or the world reversed. In: Bourdieu P (ed.) Algeria 1960. Cambridge: Cambridge University Press. 
Bowlby S, Gregory S and McKie L (1997) Doing home: Patriarchy, caring, and space. Women's Studies International Forum 20(3): 343-350.

Carsten J and Hugh-Jones S (eds) (1995) About the House. Cambridge: Cambridge University Press.

Easthope H, Liu E, Judd B and Burnley I (2015) Feeling at home in a multigenerational household. Housing, Theory and Society 32(2): 151-170.

Duyvendak JW (2011) The Politics of Home. Basingstoke: Palgrave.

Gieryn T (2000) A space for place in sociology. Annual Review of Sociology 26: 463-496.

Hondagneu-Sotelo P (2017) At home in inner-city community gardens. Journal of Housing and the Built Environment 32(1): 13-28.

Horst H and Miller D (eds) (2013) Digital Anthropology. London: Bloomsbury.

Kusenbach M (2019) Belonging. In: Atkinson P, Delamont S, Cernat A et al. (eds) The Sage Research Methods Foundations. London: Sage.

Kusenbach M and Paulsen K (eds) (2013) Home: International Perspectives on Culture, Identity and Belonging. Frankfurt: Peter Lang.

Kusenbach M and Paulsen K (2019) Home/house. In: Orum A (ed.) The Wiley-Blackwell Encyclopedia of Urban and Regional Studies. Chichester: Wiley-Blackwell.

Longhurst R (2012) Feminist perspectives on home. In: Smith S (ed.) International Encyclopedia of Housing and Home. London: Elsevier.

Mallett S (2004) Understanding home. The Sociological Review 52(1): 62-89.

Martsin M and Niit T (2005) The home as a territorial system. In: García R, Uzzell D, Real E and Romay J (eds) Housing, Space and Quality of Life. Aldershot: Ashgate.

McCarthy L (2018) (Re)Conceptualising the boundaries between home and homelessness: The unheimleich. Housing Studies 33: 960-985.

Mills LS, Soulé ME and Doak DF (1993) The keystone-species concept in ecology and conservation. BioScience 43(4): 219-224.

Miranda-Nieto A, Massa A and Bonfanti S (2020) Ethnographies of Home and Mobility in Europe. London: Bloomsbury.

Paulsen K (2013) Modeling home. In: Kusenbach M and Paulsen K (eds) Home: International Perspectives on Culture, Identity and Belonging. Frankfurt: Peter Lang, pp. 25-48.

Price J (2002) The apotheosis of home and the maintenance of spaces of violence. Hypathia 17(4): $39-70$.

Rybczynski W (1987) Home: A Short History of an Idea. New York: Penguin

Smart C (2007) Personal Life. Cambridge: Polity.

Tolia-Kelly DP (2016) Visuality/Materiality: Images, Objects and Practices. New York: Routledge.

Van der Horst H (2004) Living in a reception centre. Housing, Theory and Society 21(1): 36-46.

Vanzella-Young A (2019) Time, place, and home. City \& Community 18(1): 238-256.

Walters W (2004) Secure borders, safe haven, domopolitics. Citizenship Studies 8(3): 237-260.

Werner CM, Altman I and Oxley D (1985) Temporal aspects of homes. In: Altman I and Werner C (eds) Home Environments. New York: Plenum, pp. 113-132.

Young IM (2002) House and home: Feminist variations on a theme. In: Miu C and Murphy J (eds) Gender Struggles: Practical Approaches to Contemporary Feminism. New York: Rowman and Littlefield.

\section{Author biographies}

Paolo Boccagni is Professor of Sociology, University of Trento, and principal investigator of ERC HOMInG - The home-migration nexus and MIUR HOASI - Home and asylum seekers in Italy. 
His areas of expertise include transnationalism, migration, social welfare, diversity and care. He has recently done research on the experience of home among migrant and displaced persons in a number of domains, including housing and local reception. Recent publications include Migration and the Search for Home (Palgrave, 2017) and co-edited Special issues of the Journal of Housing and the Built Environment (2017) and of the International Journal of Comparative Sociology (2019).

Margarethe Kusenbach is Associate Professor and Associate Chair in the Department of Sociology, University of South Florida, Tampa. Her research interests and areas of publication include urban and community sociology, social psychology (identity and emotions), disasters and environment, and qualitative research methods. For the past several years, her work has focused on issues of home and belonging among mobile home residents and lifestyle migrants, while her new research investigates the intersection of street art and urban development in non-metropolitan cities.

\section{Résumé}

Le chez-soi (home) est quelque chose d'important, dans la vie quotidienne des gens et pour la recherche sociale, et n'a pourtant pas encore fait l'objet d'une analyse sociologique systématique. Pour contribuer à élaborer un cadre de référence, nous définissons le chez-soi comme une relation mise en place qui privilégie certains contextes socio-matériels par rapport à d'autres, en vertu des valeurs émotionnelles, affectives et pratiques qui leur sont attachées, sous des formes et à des degrés qui évoluent dans l'espace et le temps. Cette approche met en évidence l'interdépendance entre les aspects relationnels, culturels et structurels du chez-soi en tant qu'expérience sociale particulière. Nous relions ensuite le débat sociologique au discours sur le chezsoi dans le cadre plus large des sciences sociales, en mettant particulièrement l'accent sur l'heuristique, les pratiques et le caractère multiscalaire du chez-soi. En matière de recherche pratique, les bases méthodologiques des home studies, les études sur le chez-soi, sont encore en phase de développement, notamment en ce qui concerne les perspectives de traduction et de comparaison du chez-soi dans des contextes socioculturels et spatiaux différents. Ce numéro spécial de Current Sociology ouvre néanmoins de nouvelles voies pour faire avancer le domaine des home studies - au plan théorique dans notre article d'introduction, et au plan empirique dans les six articles qui suivent.

\section{Mots-clés}

Chez-soi, culture, méthodes, recherche comparative, relations, sociologie, structures sociales

\section{Resumen}

El hogar (home) es algo importante en la vida cotidiana de las personas y para la investigación social, a través de formas que aún carecen de un marco de análisis sociológico sistemático. Tratando de contribuir a este marco, se define el hogar como una relación emplazada que prioriza ciertos contextos socio-materiales sobre otros, en virtud de los valores emocionales, afectivos y prácticos que se les atribuyen, en formas y grados que cambian en el espacio y el tiempo. Este enfoque destaca la 
interdependencia entre los aspectos relacionales, culturales y estructurales del hogar como una experiencia social distintiva. Luego se conecta el debate sociológico con el discurso sobre el hogar en las ciencias sociales de manera más amplia, con un énfasis particular en la heurística, las prácticas y la multiescalaridad del hogar. En términos de investigación aplicada, las bases metodológicas de los 'estudios del hogar' están todavía en fase de desarrollo, especialmente en lo que se refiere a las perspectivas de traducir y comparar el hogar en contextos socioculturales y espaciales diferentes. Sin embargo, este número monográfico de Current Sociology abre nuevas vías para avanzar en el campo de los home studies, en el plano teórico a través de este artículo inicial, y en el plano empírico a través de los seis artículos que siguen.

\section{Palabras clave}

Cultura, estructuras sociales, hogar, investigación comparada, métodos, relaciones, sociología 